\title{
Characterization and Application of the Makoua Clay in the Chemical and Bacteriological Depollution of Gutter and Well Waters of Brazzaville
}

\author{
Ferland Ngoro-Elenga1,2*, Atipo Itoua Ngopoh'1, Hilaire Elenga',3, Jean-Romuald Mambou ${ }^{3}$, \\ Jude Novelgi Ngakosso Ngolo ${ }^{1}$, Timothée Nsongo ${ }^{1,2,3}$ \\ ${ }^{1}$ Faculté des Sciences et Techniques, Université Marien Ngouabi, Brazzaville, Congo \\ ${ }^{2}$ Groupe de Recherches sur les Propriétés Physico-chimiques et Minéralogiques des Matériaux, Université Marien Ngouabi, \\ Brazzaville, Congo \\ ${ }^{3}$ Centre de Recherches Géologiques et Minières, Brazzaville, Congo \\ Email: ^fngoroelenga@gmail.com
}

How to cite this paper: Ngoro-Elenga, F., Ngopoh, A.I., Elenga, H., Mambou, J.-R., Ngolo, J.N.N. and Nsongo, T. (2021) Characterization and Application of the Makoua Clay in the Chemical and Bacteriological Depollution of Gutter and Well Waters of Brazzaville. Materials Sciences and Applications, 12, 263-275.

https://doi.org/10.4236/msa.2021.126018

Received: April 19, 2021

Accepted: June 20, 2021

Published: June 23, 2021

Copyright $\odot 2021$ by author(s) and Scientific Research Publishing Inc. This work is licensed under the Creative Commons Attribution-NonCommercial International License (CC BY-NC 4.0). http://creativecommons.org/licenses/by-nc/4.0/ (c) (i) (8) Open Access

\begin{abstract}
In this work, the authors made aquatic filters according to the formulation "clay stabilized at $4 \%$ of cement mixed with $4 \%$ of kambala sawdust and $10 \%$ of white sand" then heated to $1050^{\circ} \mathrm{C}$ to decontaminate the waters of gutters and wells. The authors carried out geotechnical, geochemical, thermal, infrared spectroscopy, and scanning electron microscopy that analyzed the clay material. Geotechnical analyzes have shown that this material is made up of $22 \%$ thin sand, $22 \%$ of silt, and $56 \%$ of clay with 26 plasticity index. The geochemical analysis showed the presence of trace elements shared out as follows: $3 \%$ of alkaline metals, $24 \%$ of alkaline earth metals, $46 \%$ of transition metals, $10 \%$ of metal, $16 \%$ of lanthanides, $1 \%$ of actinides. The most abundant trace elements are barium (19\%), vanadium (12\%), chromium (11\%) and zinc (9\%). The thermal and microscopic analyzes revealed the kaolinitic nature of materials. The chemical depollution studies have shown elimination yields of $50 \%-52.38 \%$ of sulphates; $77.33 \%$ - $85.19 \%$ of phosphates; $34.85 \%$ $88.49 \%$ nitrates; 91.3 - 100 of sulphides; The removal of bacteriological pollution are $92.8 \%-98 \%$ of total germs; $94 \%-97 \%$ of total coliform and $95 \%-$ $98 \%$ of E. coli.
\end{abstract}

\section{Keywords}

Clay Characterization, Chemical Depollution, Bacteriological Depollution, Gutter and Well Water, Makoua 


\section{Introduction}

This work is part of the geo-material research program initiated by the ministry of mines and geology through the Geological and Mining Research Center (CRGM) of the Republic of Congo, in collaboration with Marien Ngouabi University. It's based on the priority directions research defined by the government on the valorization of local materials. The Republic of Congo possesses abundant clayey sites almost unexploited, while most of the clay-based products are imported and their cost on the market is very expensive. Until then the exploitation of the clay in the Republic of Congo remains artisanal (briquetery, pottery). Thus, the identification of clay sites and the knowledge of geotechnical, physicochemical, mineralogical, thermal properties of these clays for industrial development become a priority.

The work contributes to relieving the environmental problem in general and waste management in particular, which is now an integral part of the development strategies designed and implemented in each country at the national level as the sectoral level. The forest industry is a significant source of pollution. Indeed, sawmills generate wood waste which, most often, are burned and release carbon dioxide that attacks the ozone layer. Many works [1]-[8] were realized for recycling the wood waste in the manufacture of composite materials. Several researches [6] [9] have shown that incorporation of wood waste increases the porosity and reduces the mechanical resistance into terracotta and compressed blocks.

In this work, the authors made up aquatic filters according to the formulation "clay stabilized at $4 \%$ of cement mixed with $4 \%$ of kambala sawdust and $10 \%$ of white sand" then heated to $1050^{\circ} \mathrm{C}$ to reduce chemical and bacteriological pollution of water.

\section{Materials and Methods}

\subsection{Characterization of the Raw Material}

The materials used in this work are clay, sand, cement, and kambala sawdust. Different analyzes were performed on the clay, main material, coming from the Makoua city, in the department of the Cuvette in the Republic of Congo, whose coordinates of sampling site are: position $\mathrm{N} 00^{\circ} 00.453$; E $015^{\circ} 35.364$; altitude: 333 meters [7]. These are geotechnical, geochemical, thermal, by infrared spectroscopy and scanning electron microscopy analyzes.

Geotechnical analyses made up on the soil material are granulometric analysis [10] [11]; the limits of Atterberg [12] and the Proctor test [13]. The geochemical analysis, namely the analysis of trace elements, was made with a Thermo ICPMS X7 device. Thermal analyzes have been made up on a SDT Q600 apparatus in the range $25^{\circ} \mathrm{C}-1100^{\circ} \mathrm{C}$ with the heating rate $10^{\circ} \mathrm{C} / \mathrm{min}$ in atmospheric air conditions. An infrared spectrum of the material was realized in the range of $4000-400 \mathrm{~cm}^{-1}$. The observation of the platelet morphology of this material according to different dimensions of $1 \mu \mathrm{m} ; 2 \mu \mathrm{m} ; 5 \mu \mathrm{m} ; 10 \mu \mathrm{m}$ and $20 \mu \mathrm{m}$ was performed by scanning electron microscopy under $10 \mathrm{kV}$ voltage. 


\subsection{Making Filters and Analyzes of Waters}

The aquatic filters were made with the formulation "clay stabilized at $4 \%$ of cement mixed with $4 \%$ of kambala sawdust and $10 \%$ of white sand" then heated to $1050^{\circ} \mathrm{C}$. The samples of wastewater from gutters and wells were analyzed before and after filtration to determine the concentrations of chemical and bacteriological elements that can be considered as pollution indicators. The samples were taken in aseptic conditions. Water sample have been conserved in a cooler (icebox) at $4^{\circ} \mathrm{C}$ to avoid a very large variation of the initial quantity in germ and maintain the metabolism of microorganisms during transportation of the place of sampling to the laboratory.

\subsubsection{Chemical Depollution}

Colorimetric, comparative, titrimetric and numerical methods were used to perform the physico-chemical analysis. The compounds found in the wastewater are very numerous and varied. To determine the degree of pollution, it is not necessary to identify all the chemical compounds present in waters but use the globall parameters that correspond to the main pollution [14]. Referring to the French decree of December 22, 1994, we found the following parameters: particulate pollution due to suspended materials, nitrogen pollution $\left(\mathrm{NH}_{4}^{+}, \mathrm{NO}_{2}^{-}\right.$ and $\mathrm{NO}_{3}^{-}$); phosphorus pollution. Added to this parameter, the pollution due to sulphates and sulphides. The yield chemical pollutants are determined by the following relation:

$$
R(\%)=\frac{P_{i}-P_{0}}{P_{i}} \times 100
$$

$R(\%)$ : percent removal efficiency; $P_{\dot{i}}$ concentration of the chemical parameter of the raw water; $P_{0}$ : concentration of the chemical parameter of filtered water.

\subsubsection{Bacteriological Depollution}

The indicator elements of this pollution are the total germs, fecal coliforms or Escherichia coli (E. coli). The research and counting of total coliforms and of $E$. coli was done according [15] [16]. For the bacteriological analysis charges, the rate of abatement or elimination efficiency was calculated in percentage and in logarithmic unit by the following formulas [17] [18]:

$$
R(\%)=\frac{P_{i}-P_{0}}{P_{i}} \times 100 \text { ou } R(\mathrm{u} . \log )=-\log _{10}\left(1-\frac{R(\%)}{100}\right)
$$

$R(\%)$ : rate of abatement or percent removal efficiency; $R(\mathrm{u} . \log )$ : rate of abatement in logarithmic unit; $P_{i}$ : concentration of the raw water parameter; $P_{0}$ : concentration of the parameter of the filtered water.

\section{Results and Discussion}

\subsection{Geotechnical Analyzes}

The granulometric analysis has shown that the clay material consists of $22 \%$ of thin sand, $22 \%$ of silt and $56 \%$ of clay. The percentage of the elements lower to 2 
$\mu \mathrm{m}$ of this material is good for using in the ceramic industry [19] [20]. Thus, Atterberg limits of this material are such that:

\begin{tabular}{ccc}
\hline liquidity limit & plasticity limit & plasticity index \\
\hline 54.1 & 28.1 & 26 \\
\hline
\end{tabular}

According to the classification of soils according to their plasticity index, a ground has high swelling potential when its index is between 20 and 25 [21]. Therefore, AMK1 ground with a plasticity index 26 exhibits high swelling and this swelling character could depend on the quantity and type of clay minerals present [22] [23] [24]. The swelling potential and the high plasticity index of this material could probably be related to the presence of smectite or montmorillonite. This plasticity index could be reduced by associating either cement or lime on this ground [22] [25]-[30]. The activity of this material, or the ratio of the plasticity index and the percentage of elements inferior to $2 \mu \mathrm{m}$, is 0.46 . This material would be an inactive clay so kaolinitic because its activity is inferior to 0.75 .

\subsection{Geochemical Analyzes}

In this work, the authors determined trace elements in the main material. The analysis of major and minor elements was carried out by [7] and showed that this material is essentially aluminosilicate. The results of the analysis of trace elements are presented in Figure 1 and Figure 2. In Figure 1, the authors only

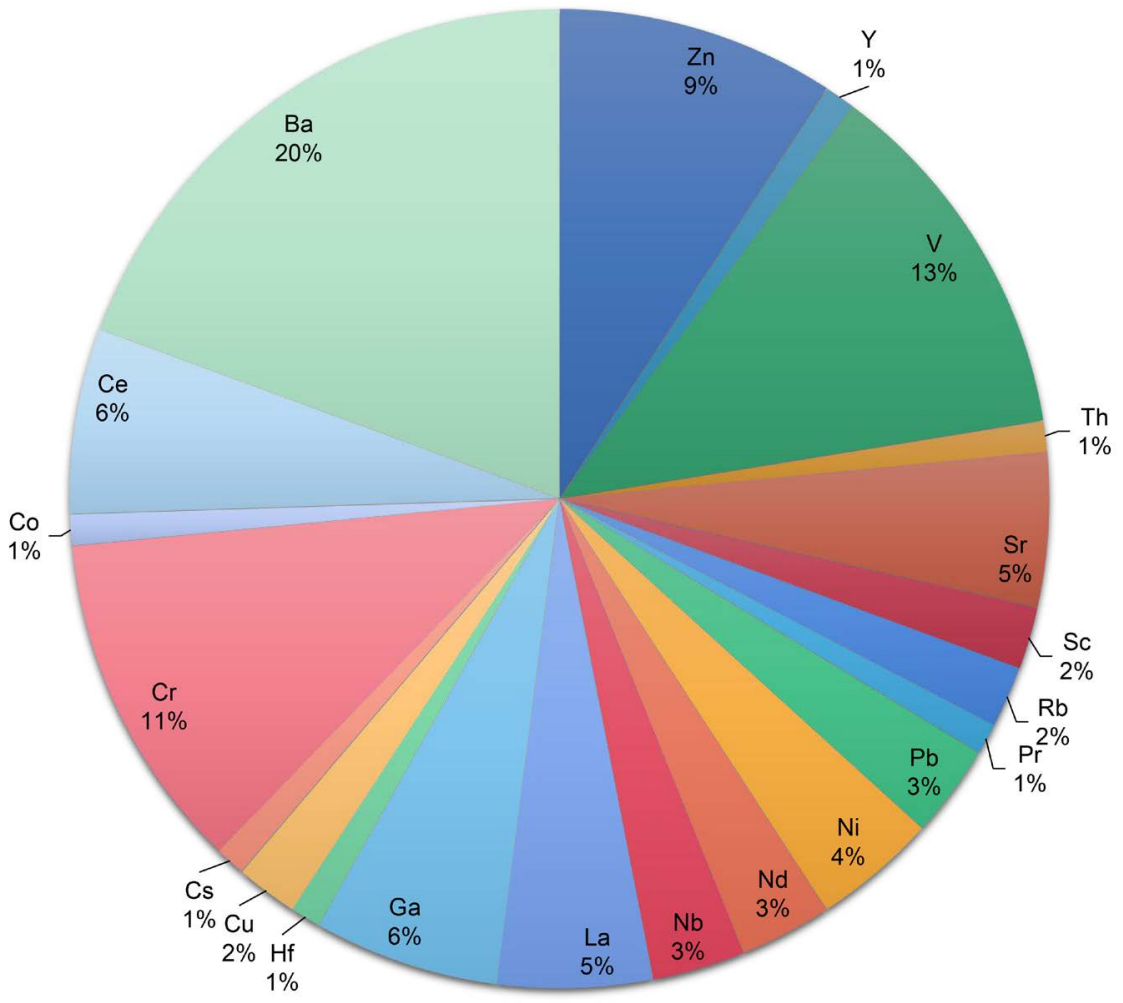

Figure 1. Trace elements content in clay material. 


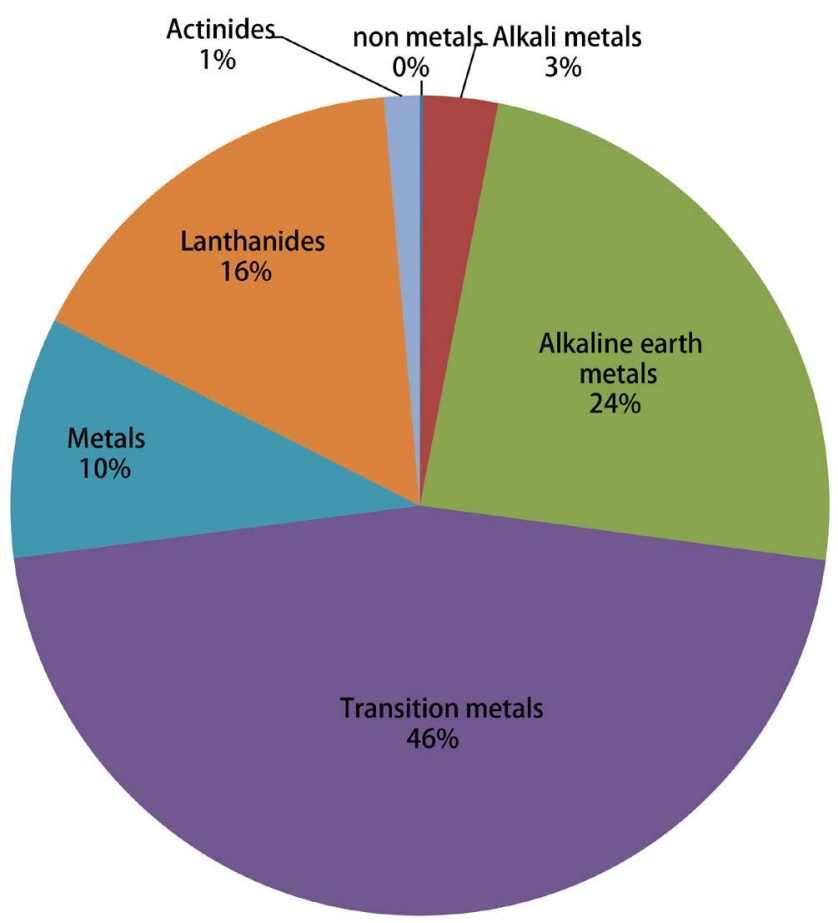

Figure 2. Percentage of trace elements groups in the clay material.

present the trace elements with a percentage greater than or equal to 1 . The following element As, Yb, W, U, Tm, Ta, Tb, Sb, Sn, Sm, Mo, Lu, In, Ho, Gd, Dy, $\mathrm{Er}, \mathrm{Be}$, and $\mathrm{Cd}$ have almost zero weight percentages.

Among the traces elements of the clay material, we noted the presence of a non-metal such as Arsenic (As), alkali metals ( $\mathrm{Rb}, \mathrm{Cs}$ ), alkaline-earth metals (Be, $\mathrm{Sr}, \mathrm{Ba}$ ), transition metals ( $\mathrm{Sc}, \mathrm{V}, \mathrm{Cr}, \mathrm{Hf}, \mathrm{Cu}, \mathrm{Co}, \mathrm{Ni}, \mathrm{Zn}, \mathrm{Y}, \mathrm{Nb}, \mathrm{Mo}, \mathrm{W}, \mathrm{Cd}$ ), metals (Ga, Ge, In, Sn, Sb, Pb, Bi), lanthanides (Ce, La, Dy, Er, Eu, Gd, Ho, Lu, $\mathrm{Nd}, \mathrm{Pr}, \mathrm{Tb}, \mathrm{Yb}, \mathrm{Sm}$ ) and actinides (Th, U). It appears that the most abundant trace elements in this material are $\mathrm{Ba}(19 \%), \mathrm{V}$ (12\%), Cr (11\%), and Zn (9\%). We also noted the different percentages of the families of the trace elements in the presence, namely $3 \%$ of the alkaline metals, $24 \%$ of alkaline-earth metals, $46 \%$ of transition metals, $10 \%$ of metals, $16 \%$ of lanthanides et $1 \%$ of actinides.

\subsection{Thermal Analysis}

The curves resulting from ATG/ATD/DTG thermal analyzes are below represented by Figure 3.

These histograms are subdivided into two areas: the first is $25^{\circ} \mathrm{C}$ around $500^{\circ} \mathrm{C}$ and the second ranges from $600^{\circ} \mathrm{C}$. The peak located between $25^{\circ} \mathrm{C}$ and $100^{\circ} \mathrm{C}$, with a mass loss of $1.649 \%$ corresponds to the dehydration of the material and the exothermic, which is $254.57^{\circ} \mathrm{C}$ with a loss of $1.622 \%$ corresponds to the decomposition of organic matter. The endothermic peak at $495.64^{\circ} \mathrm{C}$ corresponds to the dehydroxylation of kaolinite to give metakaolinite. The peak at $571.69^{\circ} \mathrm{C}$ could correspond to the phase transition of quartz $\alpha$ and quartz $\beta$ [31] [32] [33]. Accidents at $495.64^{\circ} \mathrm{C}$ and $571.69^{\circ} \mathrm{C}$ are accompanied by a mass loss of 


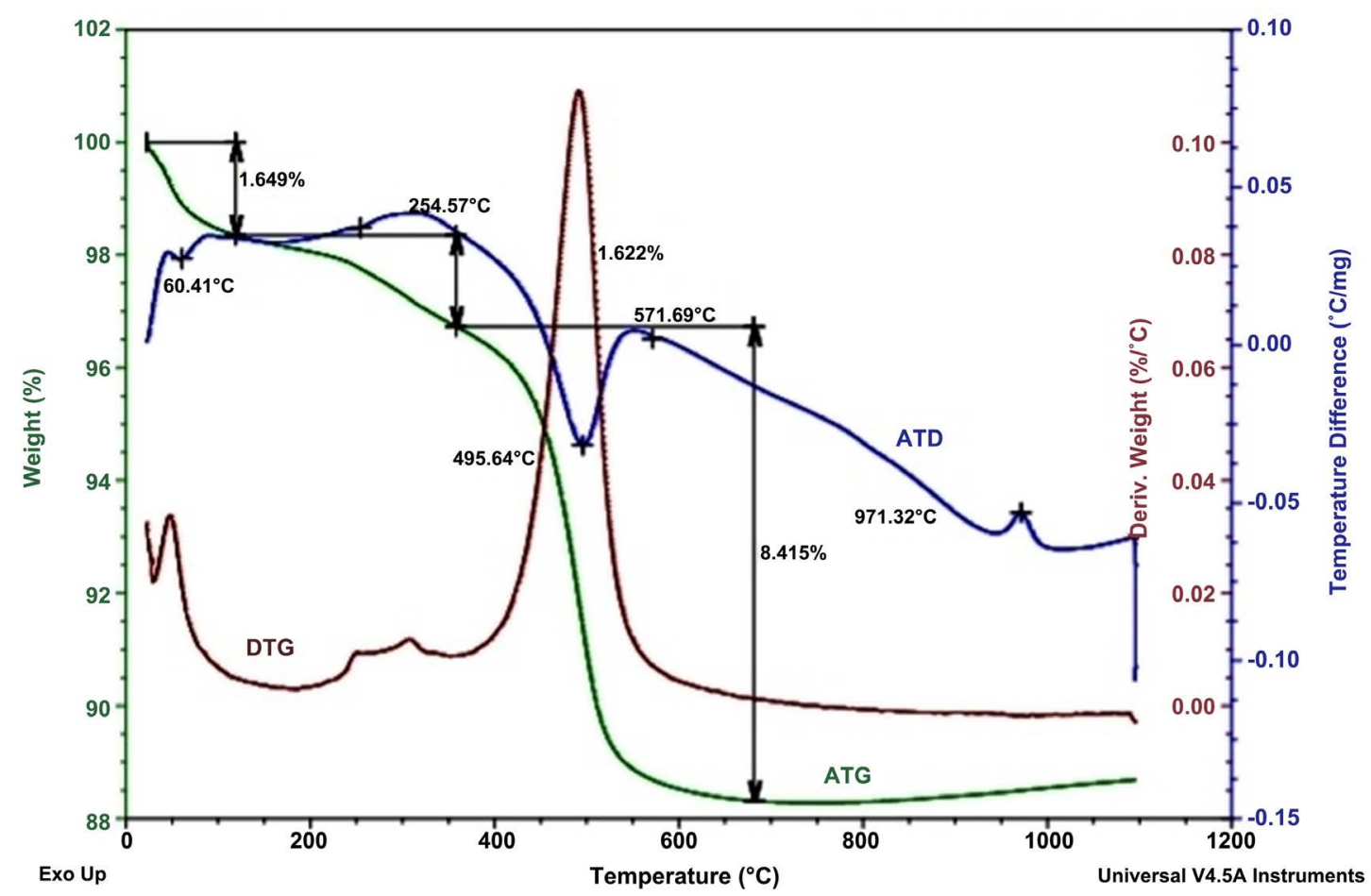

Figure 3. Thermal analyzes of clay material.

$8.415 \%$. The exothermic peak observed at $971.32^{\circ} \mathrm{C}$ could be explained by the structural organization of metakaolinite to give the mullite following the transformation [3] [34] [35]:

$$
\begin{aligned}
& 3\left(2 \mathrm{SiO}_{2}, \mathrm{Al}_{2} \mathrm{O}_{3}\right) \rightarrow 4 \mathrm{SiO}_{2}+2 \mathrm{SiO}_{2}, 3 \mathrm{Al}_{2} \mathrm{O}_{3} \\
& \text { Metakaolin Silice amorphous Mullite }
\end{aligned}
$$

\subsection{Infrared Spectrum}

Figure 4 shows infrared spectrum of the raw material in the range of $4000-400$ $\mathrm{cm}^{-1}$.

The absorption bands located between $3688.78 \mathrm{~cm}^{-1}$ and $3619.02 \mathrm{~cm}^{-1}$ correspond to the vibrations of the hydroxyl. These bands [33] [36] and those between $792 \mathrm{~cm}^{-1}$ and $748 \mathrm{~cm}^{-1}$ [37] [38] indicate the presence of kaolinite. The bands at $1114 \mathrm{~cm}^{-1}$ and $1023 \mathrm{~cm}^{-1}$ correspond to the vibrations of the Si-O valence [33] [39]. The bands located at $522 \mathrm{~cm}^{-1}$ is related to the Al-O-Si vibration [33] [40] [41]. The band located around $1600 \mathrm{~cm}^{-1}$ could be attributed to the bending of the $\mathrm{H}-\mathrm{OH}$ bonds of the structural water molecules and that at 908 $\mathrm{cm}^{-1}$ to the bending vibrations of the $\mathrm{Al}-\mathrm{Al}-\mathrm{OH}$ and $\mathrm{Al}-\mathrm{Mg}-\mathrm{OH}$ groups indicating the presence of smectite [42] [43]. These results confirm the presence of kaolinite and montmorillonite in the material. They corroborate with those of the $\mathrm{X}$-ray diffraction found [8] and those of the thermal analysis.

\subsection{Scanning Electron Microscopy}

Scanning electron microscopy of clay material is presented in Figure 5. 


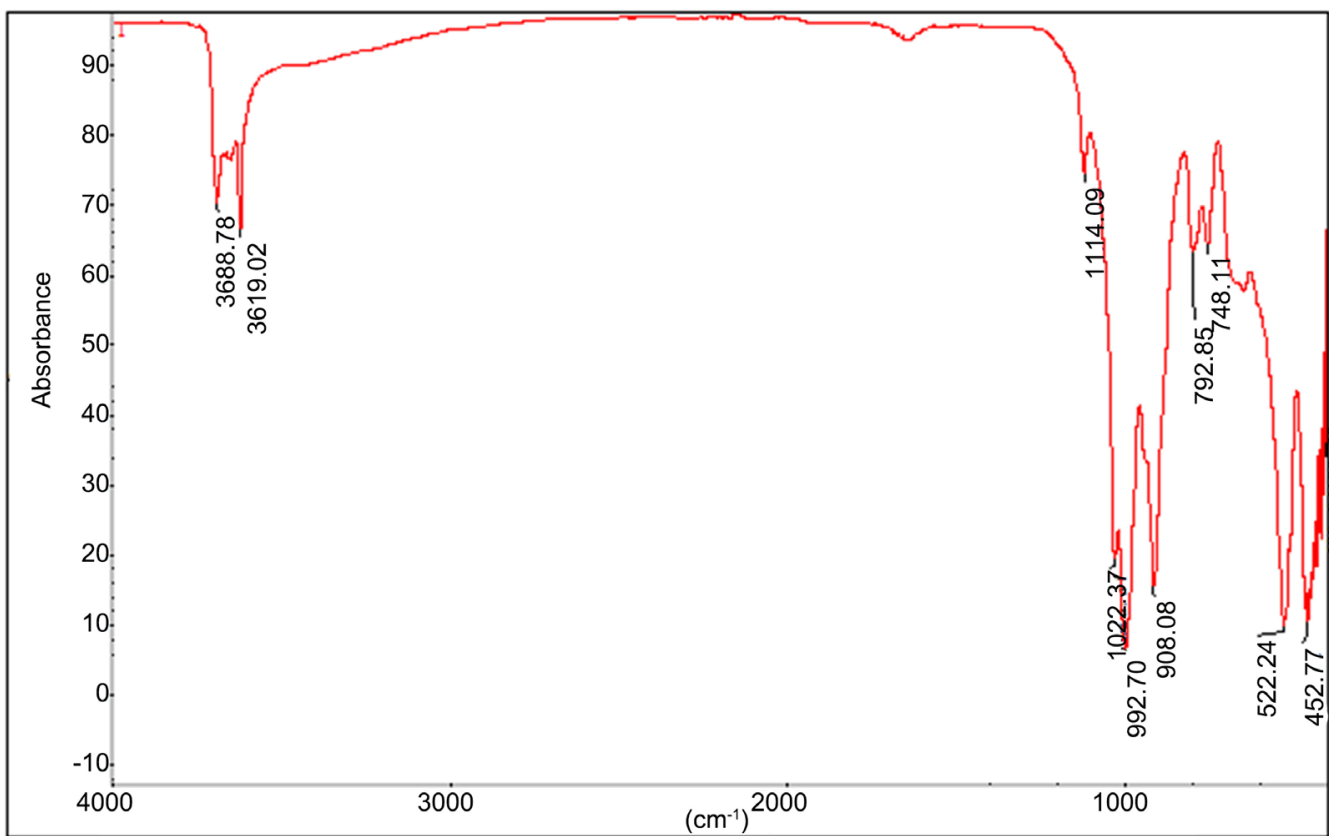

Figure 4. Infrared spectrum of clay material.
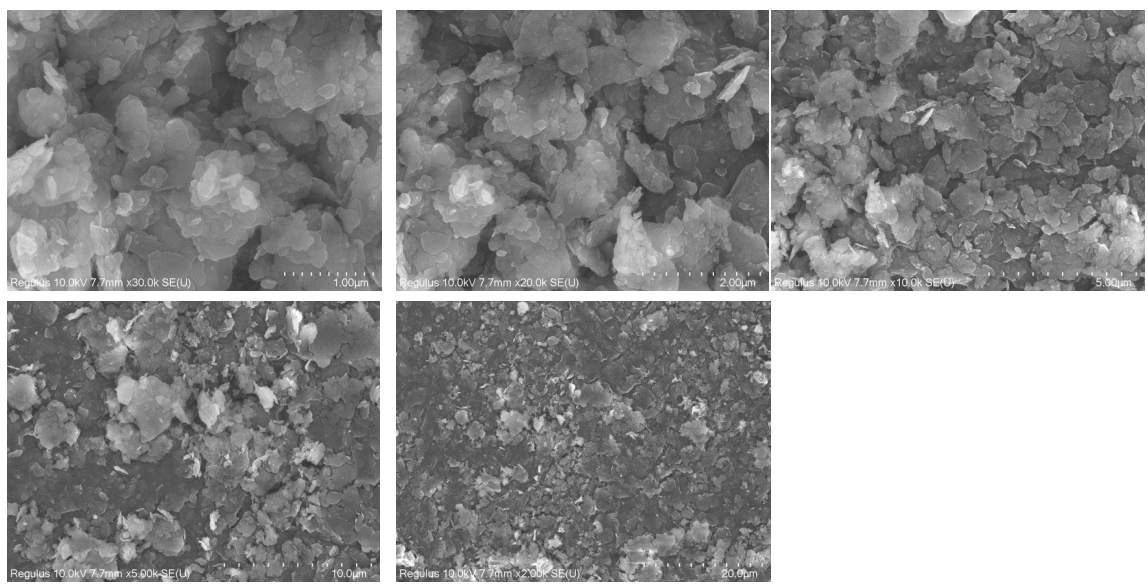

Figure 5. Scanning electron microscopy of clay material.

The clay particules appear in the form of clusters with irregular contours. This is a morphology encountered by poorly crystallized kaolinite. This observation is also made by [32] [38].

\subsection{Chemical Depollution}

Figure 6 and Figure 7 show the physical parameters and chemical elements of the different types of water before and after filtration.

The yields of percentage removal efficiency of elements susceptible to be considered as chemical pollution indicator elements are presented in Figure 8.

The filters have virtually eliminated particulate pollution due to suspension matter; which would be justified by the decrease in turbidity of $95.7 \%$ for well water and $99.32 \%$ for gutter water. These results are consistent with those found 


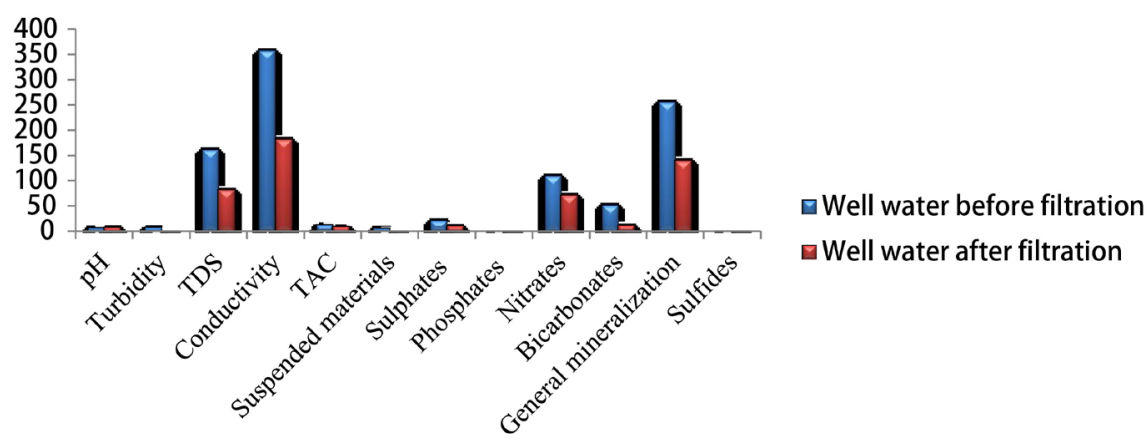

Figure 6. Physical parameters and chemical elemens of well water before and after filtration.

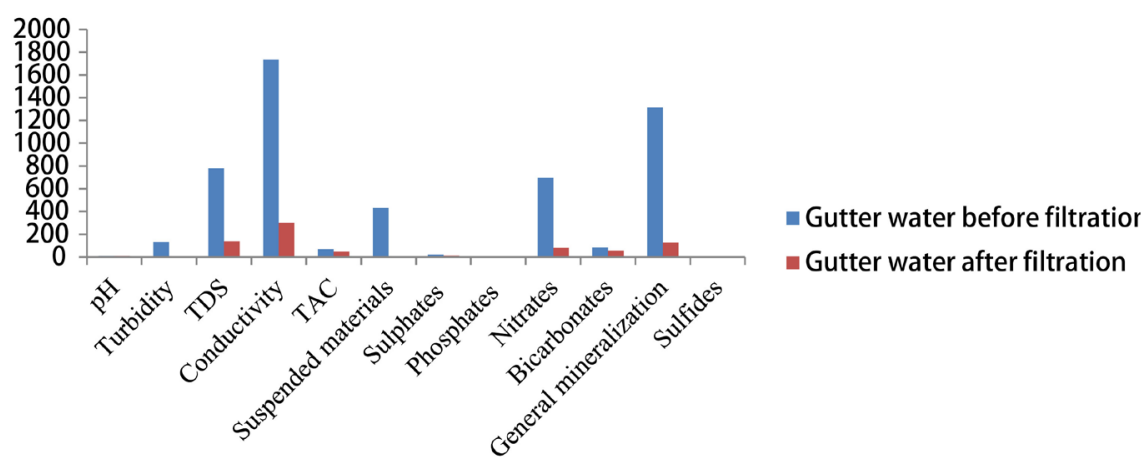

Figure 7. Physical parameters and chemical elements of the gutter water before and after filtration.

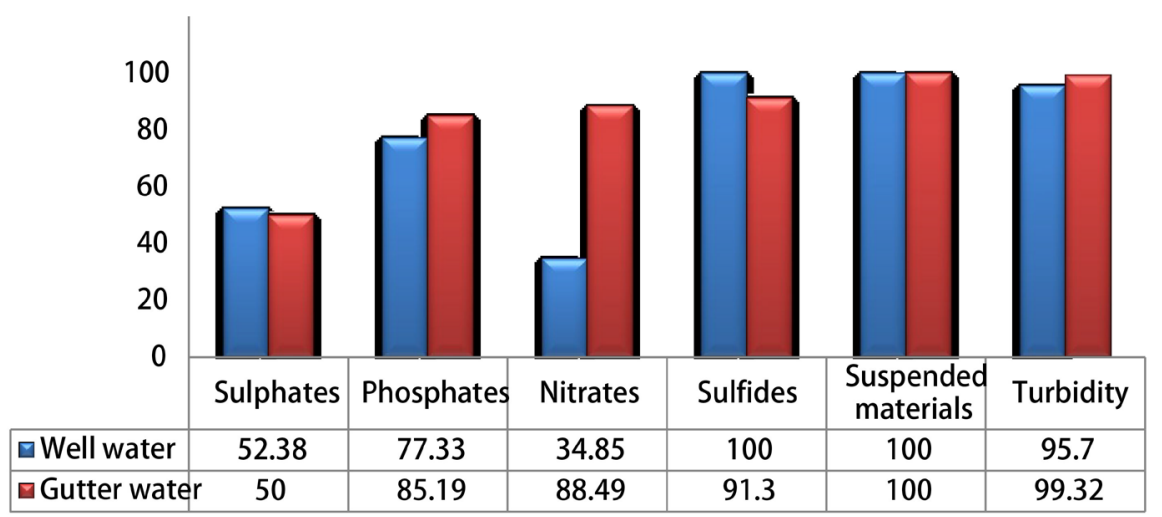

Figure 8. Yield of percentage removal efficiency of chemical pollutants.

by [18]. On the one hand, the filters removed $52.38 \%$ of sulphates, $77.33 \%$ of phosphates and $100 \%$ of sulphides in well water and on the other hand, we saw a decrease of $50 \%$ of sulphates, $85.19 \%$ of phosphates, $88.49 \%$ of nitrates and $91.30 \%$ of sulphides in the gutter water. Analysis of nitrates in well water shows a low decrease of $34.85 \%$; which could be due to the recontamination of the water after filtration.

\subsection{Bacteriological Depollution}

The results obtained are presented in the following Figure 9 and Figure 10: 


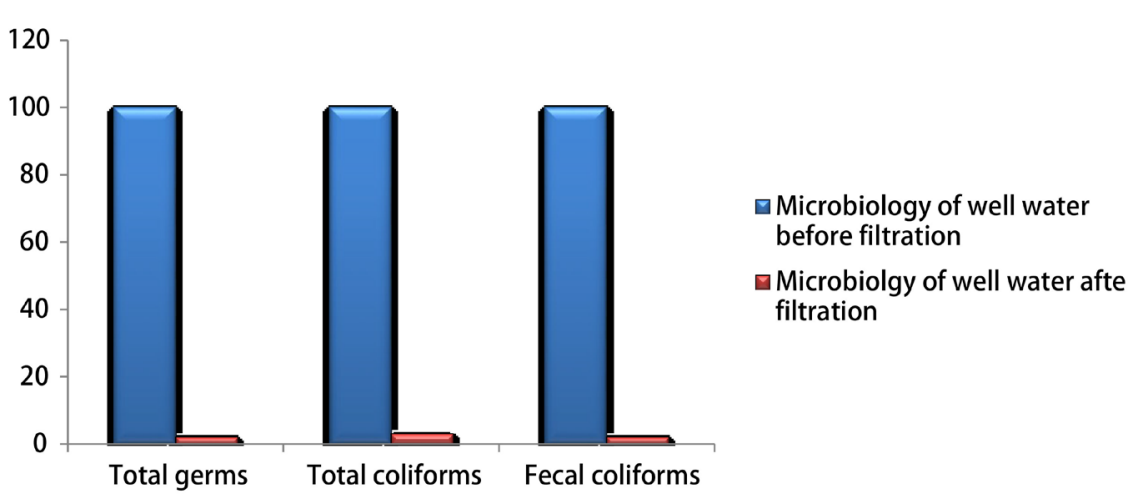

Figure 9. Microbiology of well water before and after filtration.

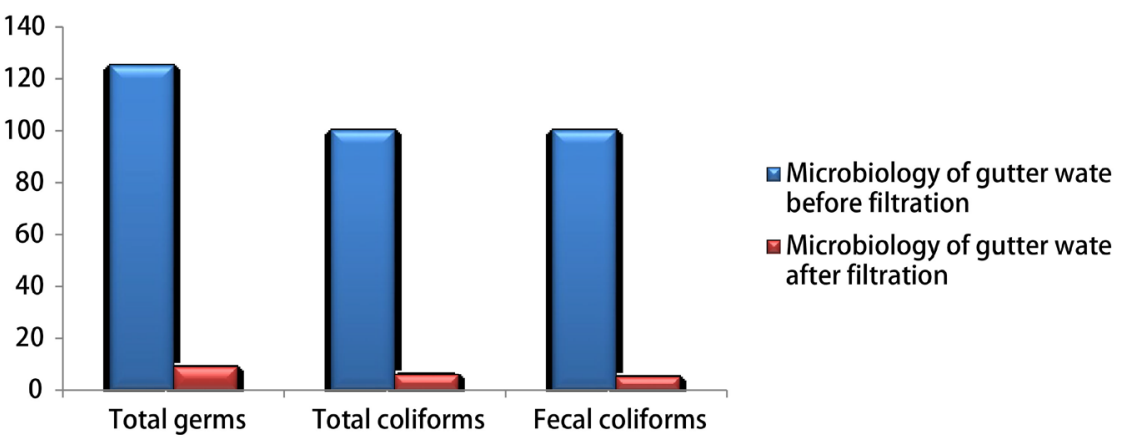

Figure 10. Microbiology of gutter water before and after filtration.

The bacteriological retention capacities in percentage and in logarithmic unit of water are presented in Figure 11 and Figure 12.

The microbiological analyzes have shown considerable elimination of bacteria. The minimum percent removal efficiency in well water is $98 \%$ for total germs, $97 \%$ for total coliforms and $98 \%$ for fecal coliforms or $E$. coli and in gutter water, this yield is $92.8 \%$ for total germs, $94 \%$ for total coliforms and $95 \%$ pour fecal coliforms.

The minimum elimination efficiency yield in logarithmic unit for fecal coliforms or E. coli is 1.30 u.log for gutter water and 1.69 u.log pour well water. This elimination is acceptable because its yield is greater than $1 \mathrm{u} . \log$, which is the value of logarithmic reduction below which the traitment of fecal coliforms is not effective [18] [44]. The minimum values of our study remain slightly lower than those of [18] but higher than those of [45] [46] as shown in the Figure 13. This could be explained in part by the fact that the combustible and the degreaser used are not the same. Several studies on ceramic filters use rice husks as combustible and chamotte as a degreaser unlike sawdust and sand used in this study. This elimination could be explained by the fact that during cooking, the sawdust entering into the composition of filter are consumed by releasing carbon dioxide that gives a porous appearance to filters. These micropores would therefore be able to trap the chemical and bacteriological elements of the water. 


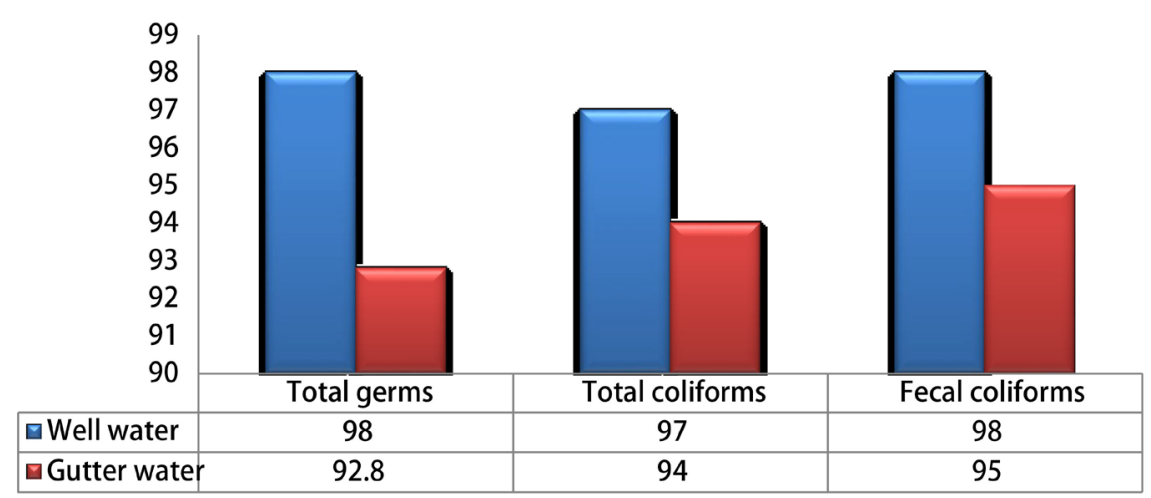

Figure 11. Yield minimum elimination in percentage of bacteriological pollutants.

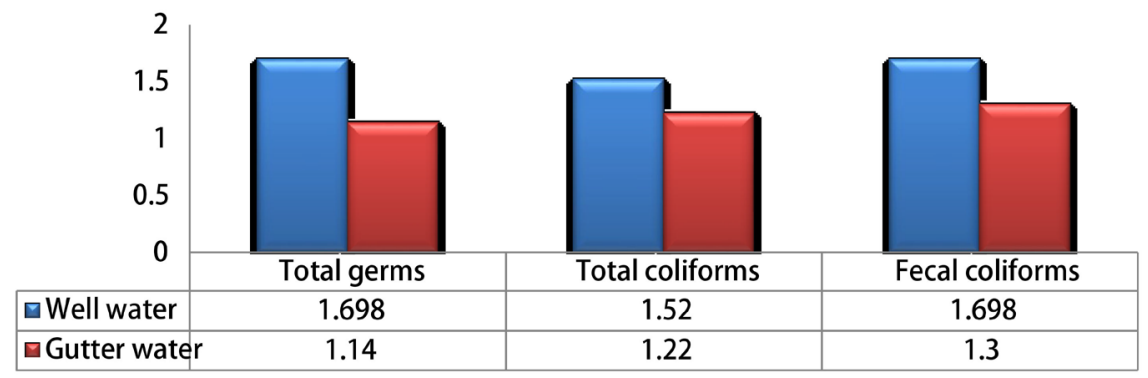

Figure 12. Elimination efficiency yield in logarithmic unit of bacteriological pollutants.

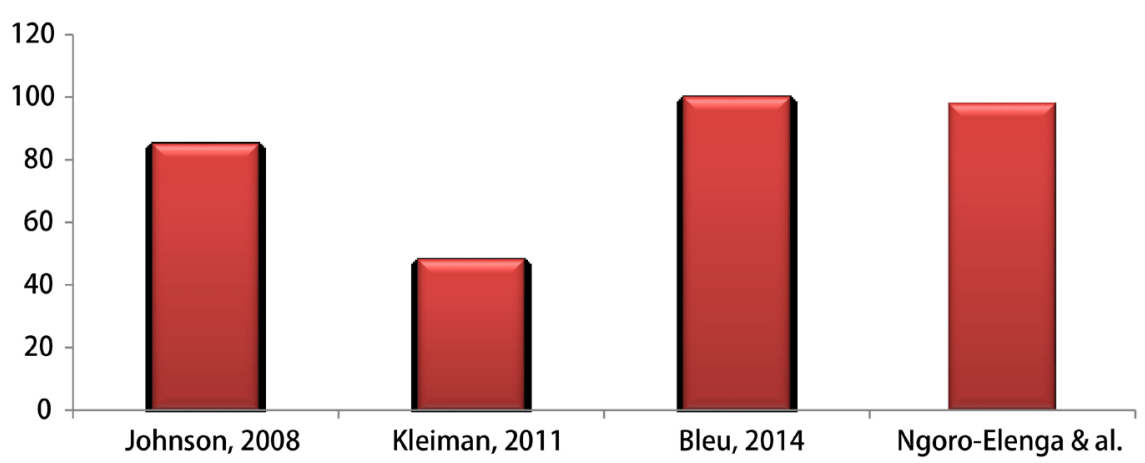

Figure 13. Yields comparison of minimum elimination yields in fecal coliforms or E. coli.

\section{Conclusion}

Geotechnical studies have shown that this material consists of $56 \%$ of the clay fraction, $22 \%$ of thin sand and $22 \%$ of silt with a plasticity index of 26 . Geochemical analyzes also showed the presence of metallic trace elements distributed as follows: $46 \%$ of transition metals, $24 \%$ of alkaline earth metals, $16 \%$ of lanthanides, $10 \%$ of metal, $3 \%$ of alkaline metals and $1 \%$ of actinides. The most abundant trace elements are barium (19\%), vanadium (12\%), chromium (11\%) and zinc (9\%). Thermal and microscopic analyzes have shown that this soils is a kaolinite clay. The filters manufactured are capable of retaining chemical and bacteriological pollutants contained in water with retention efficiencies of 50\% $52.38 \%$ of sulphates; $77.33 \%-85.19 \%$ of phosphates; $34.85 \%-88.49 \%$ of nitrates; $91.30 \%-100 \%$ of sulphides; $100 \%$ of particulate pollution; $92.8 \%-98 \%$ of 
total germs; $94 \%$ - $97 \%$ of total coiforms and $95 \%-98 \%$ of E. coli.

\section{Acknowledgements}

The authors thank the Geological and Mining Research Center (CRGM) and his director general for geochemical and thermal analyzes.

\section{Conflicts of Interest}

The authors declare no conflicts of interest regarding the publication of this paper.

\section{References}

[1] Wei, Y.M., Zhou, Y.G. and Tomita, B. (2000) Study of Hydration Behavior of Wood Cement-Based Composite II: Effect of Chemical Additives on the Hydration Characteristics and Strength of Wood-Cement Composite. Journal of Wood Sciences, 46, 444-451. https://doi.org/10.1007/BF00765802

[2] Alberto, M.M., Mougel, E. and Zoulalian, A. (2001) Influence of Extractable Essences from Mozambique on Cement Hydration. Scientific Books of Woods, 2, 1-14.

[3] Govin A. (2004) Physico-Chemical Aspect of the Wood-Cement InteractionModification of Cement Hydration by Wood. Doctoral Thesis, Jean Monnet University of Saint Etienne and National School of the Mines of Saint Etienne, Saint-Étienne, 202.

[4] Ganga, G., Elenga, H., Nsongo, T. and Tamo Tatsiété, T. (2014) Effect of Environmental Temperature and $\mathrm{pH}$ Water on Compressive Strength of Clay Brick Mixed Chips Mahogany Based Building Materials. Industrial Financial \& Business Management, 2, 296-299.

[5] Ganga, G., Nsongo, T., Elenga, H., Mabiala, B., Tatsiété, T. and Nzonzolo (2014) Effect of Incorporation of Chips and Wood Dust Mahogany on Mechanical Acoustic Behavior of Brick Clay. Journal of Building Construction and Planning Research, 2, 198-208. https://doi.org/10.4236/jbcpr.2014.23018

[6] Chemani, H. and Chemani, B. (2013) Valorization of Wood Sawdust in Making Porous Clay Brick. Academic Journal, 8, 609-614.

[7] Ngoro-Elenga, F., Elenga, H., Nsongo, T. and Ganga, G. (2016) The Influence of the Nature of Plant and Mineral Wastes on Clay Slabs Resistance to Flexion-Traction. Research Journal of Materials Sciences, 4, 1-5.

[8] Ngoro-Elenga, F., Elenga, H., Nsongo, T. and Tamo Tatietsé, T. (2016) Experimental Study on the Effect of Wood Sawdust and Sand on the Clay Slabs Resistance to Compression. Research Journal of Engineering Sciences, 5, 1-6.

[9] Ganga, G. (2016) Study of the Influence of the Wood Waste Content on the Mineralogical Structure, the Mechanical and Acoustic Properties of Clay and Laterite Bricks. Doctoral Thesis, Marien Ngouabi University, Brazzaville-Congo, 149 p.

[10] Association Française de Normalisation (AFNOR) (1978) Granulometric Analysis by Sieving. NF P 18-560.

[11] Association Française de Normalisation (AFNOR) (1992) Granulometric Analysis by Sedimentation. NF P 94-057.

[12] Association Française de Normalisation (AFNOR) (1993) Determination of the Limits of Atterberg. NF P 94-051. 
[13] Association Française de Normalisation (AFNOR) (1999) Determination of Compaction References of a Material. NF P 94-093.

[14] Rejsek, F. (2002) Water Analysis: Regulatory and Technical Aspects. Edition Ressources for National Education, Bordeaux, $360 \mathrm{p}$.

[15] Association Française de Normalisation (AFNOR) (1985) Water Testing-Research and Enumeration of Coliforms and Thermotolerant coliforms-General Method by Membrane Filtration. NF T 90-414.

[16] International Organization for Standardization (ISO) (2000) Water QualityResearch and Enumeration of Escherichia coli and Coliforms Bacteria-Part 1: Method per Membrane Filtering. NF EN ISO 9308-1.

[17] Brown, J. (2007) Effectiveness of Ceramic Filtration for Drinking Water Treatment in Cambodia. Doctorate Thesis, University of North Carolina, Chapet Hill, 256 p.

[18] Bleu, E.B. (2014) Home Water Treatment: Design and Evaluation of the Efficiency of Ceramic Filters. Engineering Master's, International Institute for Water Engineering and Environment (2iE), Ouagadougou-Burkina Faso, 63.

[19] Wetshondo Osomba, D. (2012) Characterization and Valuation of Clay Minerals of the Kinshasa Province (RD Congo). Doctoral Thesis, University of Liege, Liège, $320 \mathrm{p}$.

[20] El Ouahabi, M. (2013) Industrial and Artisanal Valuation of the Clay of Morocco. Doctoral Thesis, University of Liege, Liège, $189 \mathrm{p}$.

[21] Mellal, F. (2009) Study of Physicochemical and Mechanical Behavior of a Marly Road Embankment Improved by Slaked Lime: Case of the East-West Hyghway Section Oued Fodda/Khemis Miliana. Master's Thesis, Hassiba Ben-Bouali University, Algeria.

[22] Bell, F.G. (1996) Lime Stabilization of Clay Minerals and Soils. Engineering Geology, 42, 223-237. https://doi.org/10.1016/0013-7952(96)00028-2

[23] Mahalinger-Iyer, U. and William, D.J. (1997) Properties and Performance of Lateritic Soil in Road Pavement. Engineering Geology, 46, 71-80.

https://doi.org/10.1016/S0013-7952(96)00096-8

[24] Al-Rawas, A.A. and Qararouddin, M. (1998) Construction Problems of Engineering Structures Founded on Expensive Soils and Rocks in Northern Oman. Building and Environment, 33, 159-171. https://doi.org/10.1016/S0360-1323(97)00048-6

[25] Khattab, S.A. (2002) Study of Multi-Scale of a Plastic Clay Soil Treated with Lime. Doctoral Thesis, University of Orleans, Orleans, $250 \mathrm{p}$.

[26] Akoto, B.K. and Singh, G. (1981) Some Geotechnical Properties of a Lime-Stabilized Laterite Containing a High Proportion of Aluminium Oxide. Engineering Geology, 17, 185-199. https://doi.org/10.1016/0013-7952(81)90083-1

[27] Attoh-Okine, B. (1990) Stabilization Effect of Locally Produced Lime on Selected Lateritic Soils. Construction and Building Materials, 4, 86-91.

https://doi.org/10.1016/0950-0618(90)90006-M

[28] Osula, D.O.A. (1991) Lime Modification of Problem Laterite. Engineering Geology, 30, 141-154. https://doi.org/10.1016/0013-7952(91)90040-R

[29] Osula, D.O.A. (1996) A Comparative Evaluation of Cement and Lime Modification of Laterite. Engineering Geology, 42, 71-81. https://doi.org/10.1016/0013-7952(95)00067-4

[30] Brandle, H. (1981) Alteration of Soil Parameters by Stabilization with Lime. C.R du $X^{i m e}$ congrès international de mécanique des sols et travaux de fondations, 3, Stockholm, 15-19 June 1981, 587-597. 
[31] Traoré, K. (2003) Low Temperature Sintering of Kaolinite Clay from Burkina Faso-Thermal Transformations and Structural Reaoganizations. Doctoral Thesis, University of Limoges, Limoges, 190.

[32] Konan, K.L. (2006) Interaction between Clay Material and a Basic Medium Rich in Calcium. Doctoral Thesis, University of Limoges, Limoges, 143 p.

[33] Milligo, Y. (2008) Geotechnical, Chemical and Mineralogical Study of Clayey and Lateritic Raw Materials from Burkina Faso Improved with Hydraulic Binders: Application to Civil Engineering (Building and Road). Doctoral Thesis, University of Ouagadougou, Burkina Faso, 135 p.

[34] Chen, C.Y., Lan, G.S. and Tuan, W.H. (2000) Microstructural Evolution of Millite during the Sintering of Kaolin Powder Compacts. Ceramics International, 26, 715-720. https://doi.org/10.1016/S0272-8842(00)00009-2

[35] El Yakoubi, N. (2006) Potential for the Use of Moroccan Clays in the Ceramic Industry: Case of The Jbel Kharrou and Benhmed Deposits (Moroccan Western Maseta) Doctoral Thesis, Mohammed V-Agdal University, Rabat (Morocco), 204 p.

[36] Fripiat, J.J. (1960) Application of Infrared Spectroscopy to the Study of Clay Minerals. Bulletin of the French Group of Clay, 12, 25-41.

[37] Russel, J.D. and Fraser, A.R. (1994) Infrared Methods. In: Wilson, M.J., Ed., Clay Mineralogy. Spectroscopic and Chemical Determinative Methods, CRC Press, London, 11-67. https://doi.org/10.1007/978-94-011-0727-3_2

[38] Pialy, P. (2009) Study of Same Clay Materials from the Lembo Site (Cameroon): Sintering Behavior and Analysis of Elasticity Properties. Doctoral Thesis. University of Limoges, Limoges, $130 \mathrm{p}$.

[39] Madejova, J. (2003) FTIR Technics in Clay Mineral Studies. Vibrational Spectroscopy, 31, 1-10. https://doi.org/10.1016/S0924-2031(02)00065-6

[40] Farmer, V.C. (1974) The Infrared Spectra of Minerals. Vol. 4, Mineralogical Society, London, 331-363. https://doi.org/10.1180/mono-4

[41] Truche, C. (2010) Characterization and Qualification of Clay Materials in Expansive Soils by Infrared Spectroscopy at Laboratory and Fiels Scales. Planet and Univers [Physics]. Sabatier-Toulouse III University, Toulouse, 25-41.

[42] Madejova, J., Bujdak, J., Janek, M. and Komadel, P. (1998) Comparative FTIR Study of the Structural Modifications during Acid Treatment of Dioctahedral Smectites and Hectorite. Spectrochimica Acta Part A: Molecular and Biomolecular Spectroscopy, 54, 1397-1406. https://doi.org/10.1016/S1386-1425(98)00040-7

[43] Gourouza, M., Zanguina, A., Natatou, I. and Boos, A. (2013) Characterization of a Mixed Clay Niger. Rev. Cames-Sciences Struct. Mat, 1, 29-39.

[44] Brown, J. and Sobsey, M. (2011) Evaluating Household Water Treatment Options: Health Based and Microbiological Performance Specifications. World Health Organization, Geneva.

[45] Johnson, M. (2008) Health and Water Quality Monitoring of Pure Home Water's Ceramic Filter Dissemination in the Northern Ghana. Doctorate Thesis, Massachusetts Institute of Technology, Cambridge, $146 \mathrm{p}$.

[46] Kleiman, S. (2011) Ceramic Filter Manufacturing Ghana: Water Storage and Quality Control. Research Memory, Massachusetts Institute of Technology, Cambridge, 87 p. 